\title{
RELATO DE EXPERIÊNCIA SOBRE O USO DA MÚSICA COMO METODOLOGIA ATIVA NO ENSINO DE MEDICINA
}

\author{
EXPERIENCE REPORT ON THE USE OF MUSIC AS AN ACTIVE \\ METHODOLOGY IN TEACHING MEDICINE
}

\author{
Bruna Silva Resende, Carina Scolari Gosch \\ Faculdade de Medicina - FAPAC/ITPAC Porto
}

\begin{abstract}
Music is a valuable didactic-pedagogical resource in complementing teaching, since it facilitates the understanding of content and transforms monotonous and passive classes into integrative classes, with the active participation of those involved in the process. The present study reports the experience of the use of parodies as a teaching-learning strategy for the study of the discipline of microbiology in medical graduation. This is a descriptive report. The didacticpedagogical experience was experienced at the Faculdade Presidente Antônio Carlos Porto, during the semester 2017/2. The students were divided into groups to create parodies involving topics related to microbiology. At the end, a discussion was held in the form of a dialogue to evaluate the understanding of the contents proposed for each song. Experience has shown that one must believe in the results generated by using music as a didactic-pedagogical model. It was verified that features different from traditional methods take the student out of the usual routine of the traditional method and allow the visualization of the content from another perspective, arousing the desire to learn.
\end{abstract}

Key words: Active teaching methodologies; didactic resource; microbiology.
Resumo

A música é um valioso recurso didáticopedagógico na complementação do ensino, pois facilita $o$ entendimento do conteúdo $e$ transforma aulas monótonas e passivas em aulas integrativas, com a participação ativa dos envolvidos no processo. O presente estudo relata a experiência da utilização de paródias como estratégia de ensino-aprendizagem para o estudo da disciplina de microbiologia na graduação em medicina. Trata-se de um relato de caráter descritivo. A experiência didático-pedagógica foi vivenciada na Faculdade Presidente Antônio Carlos Porto, durante o semestre 2017/2. Os discentes foram divididos em grupos para criação de paródias envolvendo temáticas relacionadas à microbiologia. Ao final, foi realizada uma discussão em forma de diálogo para avaliar a compreensão dos conteúdos propostos para cada canção. A experiência revelou que é preciso acreditar nos resultados gerados ao utilizar a música como modelo didático-pedagógico. Foi verificado que, recursos diferentes dos métodos tradicionais retiram o aluno da rotina habitual do método tradicional e possibilita a visualização do conteúdo por outra perspectiva, despertando o desejo de aprender.

Palavras chave: Metodologias Ativas de ensino; Recurso Didático; Microbiologia. 
Introdução

As novas diretrizes curriculares nacionais dos cursos de graduação em medicina impostas pelo Ministério da Educação visam à formação de médicos com postura crítica, ética, humanística e reflexiva, capacitados para atuação nos diversos níveis de atenção à saúde. Para alcançar esse objetivo as escolas médicas devem colocar em prática as metodologias ativas de ensino ${ }^{1}$.

Os novos métodos de ensino são positivos no âmbito da aquisição do conhecimento e contemplam diversos elementos em sua essência. As atividades geralmente são compostas por elementos teóricos, práticos, produções individuais, trabalhos de reflexão realizados em coletividade, além de contato com elementos da prática médica. Existe sucesso em relação à efetivação do conhecimento com o uso das metodologias ativas em comparação ao ensino tradicional, entretanto, é necessário que haja o envolvimento, engajamento, desempenho e efetiva interação entre aluno e professor ${ }^{2,3}$.

A construção do conhecimento a partir dos novos modelos de ensino instiga os alunos a se tornarem mais organizados e proativos, além de despertar a capacidade de investigação científica, responsabilizar ao próprio aluno a construção do conhecimento e aguçar o compartilhamento de saberes nas atividades em grupo ${ }^{4}$.

Nesse contexto, a música é um recurso didático-pedagógico que contribui para a formação integral do ser e possibilita o desenvolvimento de conteúdos programáticos através da transformação de conceitos espontâneos em conceitos científicos, podendo ser utilizada nas mais diversas áreas do conhecimento. Independente do domínio de técnicas musicais, a música pode ser alvo de trabalho em sala de aula de forma simples e produtiva, além de contribuir para apropriação de conteúdos e conceitos por meio da sensibilidade, uma vez que ajuda o aluno a escutar de maneira ativa e reflexiva, fixando conteúdos na memória em longo prazo ${ }^{5,6,7,8}$.

No momento em que é feito um trabalho correto e bem definido com a utilização de músicas, o aluno é capaz de aprender além do conteúdo específico de uma disciplina, o aperfeiçoamento de outras habilidades mais gerais, como a leitura e a escrita ${ }^{6}$.

Aulas teóricas muito extensas, utilizando metodologia tradicional de ensino, tornam-se maçantes e desinteressantes para a maioria dos estudantes e não têm demonstrado resultados satisfatórios em comparação às novas propostas metodológicas de ensino. Com a finalidade de chamar atenção e aumentar a satisfação e motivação dos alunos no processo de aprendizagem, a música mostra-se um recurso metodológico bastante atrativo, havendo grande aceitação por parte dos alunos. É um recurso valioso na complementação do ensino, pois facilita o entendimento do conteúdo e transforma aulas passivas em aulas integrativas, com a participação ativa dos envolvidos no processo $^{9}$.

Existem alguns obstáculos ligados ao ensino da microbiologia e as principais dificuldades estão relacionadas à natureza abstrata de alguns conteúdos, a falta de correlação entre assuntos específicos e o cotidiano, e às questões didáticopedagógicas que envolvem a disciplina. Entretanto, isso não impede a criação de novas ferramentas educacionais que facilitem a aquisição do conhecimento. A criação de paródias é um exercício interessante para aplicação de conteúdos teóricos, e quando está associada à escolha de músicas populares, com melodias que agradam os estudantes, facilita fixação da letra musical elaborada, promovendo a ampliação do ensino ${ }^{10}$.

A paródia é uma estratégia de ensino interessante para encarar o aprendizado de maneira prática, no entanto, essa atividade não deve limitar-se à simples fixação ou memorização da letra da música, pois esse recurso permite aos envolvidos atingir objetivos muito mais amplos, possibilitando situar a música na realidade dos estudantes de maneira contextualizada ${ }^{11}$.

O presente estudo visa relatar a experiência da utilização de paródias como estratégia de ensino-aprendizagem para o estudo da microbiologia na graduação em medicina.

\section{Metodologia}

O presente estudo é um relato de caso de caráter descritivo. Foi vivenciada uma experiência didático-pedagógica na Faculdade Presidente Antônio Carlos Porto- FAPAC/ITPAC PORTO. A atividade proposta foi desenvolvida durante o semestre 2017/2 na disciplina de Microbiologia, engajada no 3 o período do curso de medicina.

Diante da reforma curricular imposta pelo Ministério da Educação às faculdades de medicina foram obrigadas a adequarem sua estrutura curricular para um aprendizado baseado em metodologias ativas de ensino ${ }^{1}$. Nessa perspectiva, é necessária uma adaptação dos docentes a essa nova realidade curricular. Optou-se pela metodologia ativa de ensino baseada na música para o aprendizado de alguns 
conteúdos de microbiologia, pois mesmo que o educando não tenha domínio sobre assuntos relacionados à musicalidade, o mesmo dispõe de um sistema que ao ter contato com manifestações sonoras, de forma consciente ou inconsciente, gera o despertar de habilidades e competências que beneficiam uma relação eficaz com conteúdos específicos, sejam estes de qualquer área de estudo 6 .

Diante disso, sugeriu-se aos acadêmicos a criação de paródias envolvendo temáticas específicas da disciplina. Os discentes foram divididos em 11 grupos contendo em média cinco acadêmicos. Os temas propostos para a criação das paródias foram: Meningite bacteriana, botulismo, tétano, gangrena gasosa, raiva, molusco contagioso, coqueluche, difteria, leptospirose, arboviroses, gastroenterite. A música que serviu de melodia inspiradora foi de livre escolha aos discentes. Na letra da música criada os acadêmicos deveriam reportar, quando possível, o agente etiológico, manifestações clínicas, diagnóstico, tratamento e prevenção das doenças sugeridas como tema.

Foi estipulado um prazo de dez dias para os acadêmicos criarem a letra da música parodiada. A produção escrita foi objeto de análise pelo docente da disciplina para apreciação do conteúdo teórico. Quando necessário, foi realizada correção, substituição ou sugestões com o intuito de aperfeiçoar a conexão entre a letra da paródia e o assunto abordado.

Após a correção do texto que seria utilizado como letra da música, os alunos escolheram a forma de apresentação. Alguns grupos optaram por fazer a gravação prévia de um vídeo-clip musical e outros preferiram cantar a paródia ao vivo. Todos os grupos levaram impressas as letras das paródias para que os demais colegas pudessem acompanhar. Foi realizada, ao final das apresentações, uma discussão em forma de diálogo para análise das paródias com o intuito de observar o entendimento do conteúdo envolvido em cada canção. Após o término da atividade foi efetuada uma avaliação observacional sobre a eficiência do método didático empregado para o aprendizado dos conteúdos, com o intuito de verificar os impactos dessa metodologia de ensino na construção de um aprendizado efetivo individual e coletivo.

\section{Resultados e Discussões}

Após a proposição da atividade musical, foi possível notar surpresa por parte de alguns alunos e o estranhamento por parte de outros, pois o modelo de aprendizagem utilizando a música como recurso didático foge um pouco da realidade a que estão habituados a vivenciar.

Porém, de maneira geral, a atividade foi bem recebida pelos acadêmicos, que ficaram entusiasmados com a proposta diferenciada de aprendizagem. A música é um recurso que pode ser utilizado para diversificar e contextualizar a aprendizagem, valorizando o processo de efetivação do conhecimento. É possível ainda estreitar os laços entre aluno, professor e ciência, sendo um instrumento de motivação para os discentes e facilitador do processo de entendimento e socialização ${ }^{12}$.

Os grupos se mostraram empenhados durante o desenvolvimento das letras parodiadas, e sempre que necessário procuravam o professor da disciplina para sanar as dúvidas, pedir sugestões e acima de tudo, verificar a coerência do conteúdo explicitado na letra da canção, pois esse era o maior anseio dos envolvidos. Os alunos puderam, no decorrer da elaboração das letras das paródias, exercitar a criatividade e levantar questionamentos acerca da temática, além disso, foram estimulados a buscar esclarecimentos para dúvidas de conceitos básicos de cada doença antes de consolidar a letra da música, tornando-se, assim, colaboradores ativos no processo de construção do conhecimento. A música trabalhada como elemento lúdico pode ser utilizada para promover uma maior interação, motivação e tornar o ambiente de aprendizagem mais atrativo e descontraído ${ }^{5}$.

O trabalho em equipe teve uma repercussão positiva com a execução dessa atividade, pois todos estavam empenhados durante a criação da letra, dando sugestões que deixassem a música parodiada mais interessante. A utilização da música como recurso didático estimula o treinamento de algumas habilidades como a paciência, autodisciplina, sensibilidade, coordenação e capacidade de memorização, além de valorizar o trabalho em equipe, pois é necessário a participação em ensaios e eventos em conjunto, indispensáveis para a construção da atividade ${ }^{5,6}$.

Os pontos principais de cada temática proposta foram contemplados nas músicas criadas. A música é uma ferramenta facilitadora do aprendizado, pois estabelece sentimento de empatia entre autor/compositor e aluno ${ }^{5}$. Selecionou-se duas paródias criadas pelos alunos para ilustrar os resultados desse relato de experiência. A primeira pode ser observada a seguir, no qual os acadêmicos criaram uma paródia sobre difteria intitulada "Cuidado com a difteria" com letra inspirada na melodia da 
música "Paradinha" da cantora Anitta.

Agora eu vou falar para você

Sobre uma doença bacteriana

Ela pode te acometer

Mas essa doença dá mais em crianças

Tosse, espirro ou aperto de mão

Ou também pelo contato com o doente

São as tais formas de transmissão

A bactéria entra no nariz "da gente"

É difteria, é difteria ah ah ah ah

É difteria, é difteria ah ah ah ah

Se por acaso a garganta doeu

E de repente a febre apareceu

E se também o corpo esmoreceu

Vá logo ao médico pelo amor de Deus

É difteria, difteria ah ah ah ah

É difteria, difteria ah ah ah ah

Forma pseudomembrana

Em amígdalas e laringe

Por isso se distingue

Se a vacina foi tomada

Não tem preocupação

Você não pega não

É difteria, difteria ah ah ah ah

É difteria, difteria ah ah ah ah

Se mesmo assim a doença te pegar

Antibiótico você vai tomar

Em poucos dias vai se curar

E logo logo você vai se livrar

É difteria, difteria ah ah ah ah

É difteria, difteria ah ah ah ah

Outro exemplo de criação dos alunos foi a paródia sobre meningite bacteriana intitulada "Da meningite ninguém gosta", inspirada na música "Do jeito que a moçada gosta" dos cantores Zezé de Camargo e Luciano.

Agora eu vou te falar

Sobre meningite

Preste atenção

Três tipos de bactérias

Podem na meningite

Causar inflamação

Esse tipo de doença

Também é chamada

de meningocócica
Uma bactéria do ambiente

Vive inclusive no nariz "da gente"

Podendo não causar nenhuma complicação

Mas se você bebe todas

Se o nariz tem infecção

Ou se tem pneumonia

Facilitaria a contaminação

Se aparecer áreas róseas

E a mente tá com alteração

A nuca tá com rigidez

Eu digo para vocês

"Tá" com a inflamação

Corre pro hospital, corre

Pra fazer a punção

Ela pode levar a morte em poucas horas

E tem um alto risco de ter transmissão

E depois do diagnóstico

É a medicação

Melhor tratamento é o antibiótico

Para evitar a proliferação

A etapa de discussão das letras das paródias foi um momento de grande importância, pois foi possível perceber as principais dúvidas sobre cada assunto abordado nas canções e com as próprias letras criadas na atividade foi possível dar os esclarecimentos necessários, simplificando o conteúdo. A música parodiada permite que seja feita a aplicação do conteúdo estudado de maneira dinâmica e descontraída, cabe ao docente avaliar o aprendizado dos alunos para que tenha a dimensão do alcance dos objetivos propostos $^{13}$

Sem dúvidas, o ato de compor uma música a partir de um assunto previamente proposto motiva a criatividade e quando há o reconhecimento do bom trabalho executado o educando torna-se ainda mais receptivo a novos desafios. Para o professor, esse tipo de atividade acaba revelando que existem muitas possibilidades de se construir o conhecimento utilizando métodos diferentes das formas convencionais de ensino ${ }^{6}$.

Comparativamente às turmas anteriores, percebeu-se que houve maior envolvimento, compromisso e interesse dos acadêmicos para o aprendizado dos conteúdos propostos e uma maior aproximação com o professor.

\section{Conclusões}

A música é um elemento próximo da realidade cotidiana dos educandos, muito diferente da tortura intelectual de uma aula com método tradicional de ensino, talvez seja esse o motivo da grande satisfação dos acadêmicos após o desenvolvimento dessa atividade. 
A experiência vivenciada revela que é preciso acreditar nos resultados gerados ao utilizar a música como modelo didáticopedagógico, pois recursos diferentes dos métodos tradicionais retiram o aluno da rotina habitual para que possa visualizar o conteúdo de uma disciplina por outra perspectiva, despertando o desejo de aprender.

\section{Referências}

1. Brasil, Ministério da Educação. Conselho Nacional de Educação. Resolução № 3, de 20 de junho de 2014. Institui Diretrizes Curriculares Nacionais do Curso de Graduação em Medicina e dá outras providências. Diário Oficial da União. Brasília, 23 jun. 2014; Seção 1, p.8-11.

2. Schweller M, Wanderlei J, Strazzacappa M, Sá FC, Celeri EHRV, Carvalho-Filho MA. Metodologias Ativas para o Ensino de Empatia na Graduação em Medicina - Uma Experiência da Unicamp. Cadernos da ABEM. 2014;(10):36-46.

3. Moreira MA, Andrade MCM. Metodologias ativas no ensino superior: possibilidade ou "faz de conta"? Evidência. 2018;(15):43-57.

4. arrabeta-Júnior V. Metodologia ativa na educação médica. Revista de Medicina. 2016;(3):113-121.

5. Moreira AC, Santos H, Coelho IS. A música na sala de aula - A música como recurso didático. Unisanta Umanitas. 2014;3(1):41-61.

6. Félix GFR, Santana HRG, Oliveira Júnior W. A música como recurso didático na construção do conhecimento. Cairu em Revista. 2014;(4):17-28.

7. Silva ESP, Pereira IB, Melo SMF. O uso da música no ensino de biologia: experiências com paródias. In: I Congresso de Inovação Pedagógica em Arapiraca. VII Seminário de Estágio. 18 a 22 de maio de 2015; Arapiraca (AL). Disponível em: http://www.seer.ufal.br/index.php/cipar/article/ view/1892/1392

8. Tavares NA, Kasper FS, Freitas A, Veloso NF. Música como recurso didático. Revista Sieduca. 2017;(2):1-6.

9. Barbiero AJC, França AAP, Castro AAA, Fófano GA, Camargo GL, Ferreira IM, Rinaldi ML, Freitas RB, Torres RA, Fontes LBA. Proposta de novas metodologias para o ensino da disciplina de farmacologia nos cursos de medicina. Revista Científica Fagoc Saúde. 2017;63-69.

10. Paixão GC, Lima LA, Colaço NJO, Lima RA, Casimiro TC, Castro LHP, Pantoja LDM.Paródias no ensino de microbiologia: a música como ferramenta pedagógica. Revista eletrônica de comunicação, informação e inovação em saúde. 2017;(1):1-12.

11. Silveira MP, Kiouranis NMM. A música e o ensino de química. Química Nova na Escola. 2008;(28):1-4.

12. Wermann NS, Mager BRG, Ferraro CS, Santos FG, Bernard FL, Gotardi J, Antoniazzi LQ. Música - Paródia: Uma ferramenta de sucesso no ensino de química. In: XII Salão de Iniciação Científica da PUCRS. 3 a 7 de outubro de 2011; Porto Alegre (RS). Disponível em: http://ebooks.pucrs.br/edipucrs/anais/seminario ic/20112/5/5/1/1.pdf

13. Xavier RAG. O uso de paródias em abordagens conceituais: Vivência na formação inicial para a docência. In: Seminário Internacional de Educação Superior. Universidade de Sorocaba - UNISO. 26 a 28 de outubro de 2014; Sorocaba (SP); Anais eletrônicos. Disponível em:http://uniso.br/publicacoes/anais_eletronico s/2014/1_es_formacao_de_professores/47.pdf

\section{Endereço para Correspondência}

Faculdade de Medicina - FAPAC/ITPAC Porto

Instituto Tocantinense Presidente Antônio Carlos Porto - R. Dois, Quadra 7, S/N - Jardim do Ypes I, Porto Nacional - TO

CEP.: $77500-000$

e-mail: bruna_s.resende@hotmail.com

Recebido em 10/04/2018

Aprovado em 19/02/2019

Publicado em 30/06/2019 